\title{
Tatjana Devjak and Sanja Berčnik, Education of preschool children (In Slovene: Vzgoja predšolskega otroka), University of Ljubljana, Faculty of Education: Ljubljana, 2018; 288 pp.: ISBN 978-961-253-219-2
}

Reviewed by JURKa LePIČNIK VODOPIVEC ${ }^{1}$

The monograph Education of preschool children (authors Tatjana Devjak and Sanja Berčnik) presents a broader insight into the study of preschool pedagogy. The central subject of the monograph is the preschool period of the child's development, which extends from the child's birth to entering primary school; it also defines the notion of education as a comprehensive concept that entails various aspects, from caring for the child to the individual design of the child as a personality, and the integration of a child into human society as a collective underpinning of society and various specific individuals.

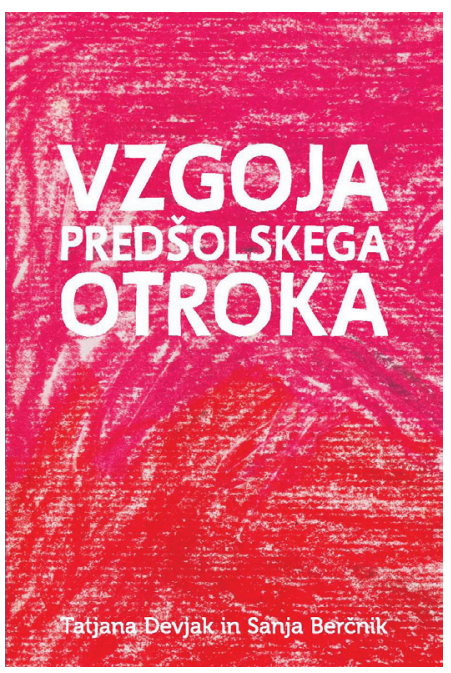

In the first chapter, Pedagogy as a science and the definition of basic concepts, the authors rightly analyse the critical concept of education and various related theories in this context. They note that education today means 'a holistic activity of people, a creative process among people, a conscious activity of shaping an individual as an individual and a social subject' (Devjak \& Berčnik, 2018, p. 10). The authors deal with the pedagogy as a science through a variety of foreign authors, including Althusser, Durkheim, Apple, and Slovenian ones, such as Medveš and Kroflič, outlining the different views and theoretical approaches to education with a focus on the education of that preschool child, which enables them to gain a critical understanding of education, especially the education of the child in the preschool period, which is supported by the notion that the modern concepts of education 'tend to gradually abolish the management of the individual, eliminate manipulation, to prepare the individual to be able to set his own educational goals and develop his own personality (self-education,

1 Faculty of Education, University of Primorska; jurka.lepicnik@pef.upr.si. 
not self-censorship)' (ibid., p. 16). The next chapter contributes to the broader understanding of education, with a historical overview of theories, concepts and views on the education of a preschool child, ranging from ancient Greek philosophers to various modern theorists such as Komenski, Pestalozzi, Locke, Rousseau, Oberlin, Owen, Froebel, Dewey, Steiner, and Montessori, discussing the history of the development of preschool institutions and the contemporary curriculum and preschool education in Slovenia.

The chapter Understanding children, childhood and children's rights brings the conceptual bases for later discussion and analyses modern theoretical concepts of understanding preschool childhood, which are pedagogically, psychologically and sociologically conceived. It is also significant that the authors introduce the understanding of the child and education as it is understood today, through the concepts of universal human and child rights (and duties). In doing so, they emphasise the empowerment of the child, when he is enabled to decide for himself and the concept of participation, which enables personal growth, strengthening of responsibility and searching for one's own individuality and identity. In addition, they point out the problematic aspects of child's rights, about which Kodelja (1995, p. 53) writes that 'they are nothing more than a multitude of regulations that allow adults to decide on their children and shape them in their own image.' The chapter concludes with the advocacy of children, which 'contributes to the awareness, that the basis of organised preschool education is built upon children's rights and not just their needs and/ or the needs of their parents, families' (Devjak \& Berčnik, 2018, p. 94).

The critical educational activities of the child in the preschool period take place through the child's play. The monograph takes this fact into account with a detailed discussion of the conceptual issues posed by play and the treatment of different types of children's play, the importance of play for children's development, the role of play as a collective or social event; this framework also includes the types and the roles of toys, in particular, the definition of a good toy. The establishment of a conceptual understanding of play and toys is, of course, essential for the proper education of preschool teachers. The authors also take into account a variety of theories and theoretical approaches, while defining the main distinction between play and work, defining work as an activity and the play as 'a tool, developing the child's skills, connection with parents and the wider world, at the same time revealing the laws of the world around him'(ibid., p. 97). For preschool pedagogy and education of preschool teachers, it is also important to understand the environments in which the child grows up or where the child's education is taking place: both the family and the kindergarten. 
In the continuation, the monograph conceptualises the family through the review of changes in European history and through the treatment of modern forms of family, its functions and tasks, changes in family life and the influence of the family on the child's personality and moral development. Since institutional education in kindergarten in relation to the family also plays a vital role in the child's preschool age, the text also discusses various models of cooperation between family and kindergarten (client, managerial, and partnership models), which are critically illuminated. The text also separates formal and informal forms of cooperation with parents, identifying the roles played by professionals or parents, which indirectly determine the model of cooperation. In the following, the monograph focuses on the kindergarten in the various functions and contexts of the kindergarten's cooperation with other institutions of society (museums, theatres, the library, health centres, etc.).

From the aspect of the conceptualisation of preschool teachers in contemporary times, it is crucial that the monograph also presents views on the education of preschool teachers through history and their professional development today. The professional development of preschool teachers is defined as the process of lifelong learning, which is the common formula in which all types of learning and education can be combined' (ibid., p. 185).

In the concluding chapters, the monograph returns to a more detailed analysis of the various current educational concepts and thematises them through the questions posed by the reform-pedagogical movement and various alternative educational concepts. It, therefore, deals entirely with conceptual questions, such as the priority of development before learning, the priority of natural education before the planned educational influence, the priority of the orientation of the education that originates from the child before the education that is based on cultural norms and values and, on this basis, also deals in detail with different directions of reform pedagogy (progressive pedagogy, pedagogy of pragmatism, and pedagogy of the working school).

The monograph Education of preschool children deals with a unified and clearly defined subject. Its argumentation is scientifically based, extensive, and theoretically relevant, and the text covers its subject in all key aspects and also consistently analyses it. The monograph includes key sources and the latest bibliography from the field, characterised by rich professional terminology. It is a transparent scientific contribution to preschool pedagogy, and it is aimed at professional educators, students of pedagogical guidelines, planners and educators in kindergartens, planners and providers of further education programs, other higher education teachers, pedagogues, psychologists, special educators and the entire professional public who are interested in this kind of problem. It 
provides a deeper insight into the understanding of the education of pre-school children and will, as such, be useful as a reference work and as a book for the professional public. The present monograph, in light of the above, represents an essential contribution to the development of pedagogy and preschool pedagogy in Slovenia. 